\title{
Menjual Tuak (Alkohol Bali) Sebuah Pilihan (Tinjauan Dari Perspektif Sosial dan Ekonomi Masyarakat di Desa Datah)
}

\author{
Kadek Rai Suwena * \\ ${ }^{1}$ Universitas Pendidikan Ganesha Singaraja Bali
}

\begin{abstract}
Abstrak
Penelitian ini bertujuan untuk mengetahui penyebab masih bertahannya pedagang tuak di Desa Datah. Karena kondisi desa yang tandus menyebabkan pekerjaan bercocok tanan lebih cocok dilakukan saat musim hujan saja, sehingga dengan demikian kondisi tanah yang seperti tersebut lebih cocok ditanami pohon aren. Selain hasil berupa minuman keras (tuak), pohon aren juga dapat memberikan manfaat ekonomis bagi pemilik pohon aren tersebut, dikarenakan hasil dari daun pohon aren tersebut dapat dijual. Selain itu daun pohon aren dimanfaatkan sebagai sarana upacara keagamaan pada saat hari raya besar seperti galungan, kuningan maupun upacara besar lainnya. Selain daun buah aren juga dapat di jual dan di konsumsi. Menyadap tuak dapat dilakukan setiap hari sehingga langsung dapat dijual ke konsumen. Jadi menjual tuak dapat dikatakan pekerjaan utama dari Desa datah. Sehingga dapat ddsimpulkan bahwa hasil dari penjualan tuak tersebut dapat digunakan untuk memenuhi kebutuhan hidup dan keluarganya. Keadaan seperti ini yang menyebabkan banyak penjual tuak tidak bisa berbuat banyak untuk hidupnya dan sulit beralih kepekerjaan lain.
\end{abstract}

\author{
Kata Kunci: \\ Tuak (Alkohol Bali), \\ Sosial dan Ekonomi, Desa \\ Datah
}

\section{Pendahuluan}

Salah satu minuman beralkohol yang pembuatannya masih tradisional adalah tuak, tuak mengandung alcohol dengan kadar 4\% (Ilyas, 2013). Dalam kehidupan sehari-hari tuak selain sebagai minuman beralkohol juga dimanfaatkan di dalam upacara-upacara keagamaan umat Hindu. Menurut Sri Arnawi (dalam Seputra, 2009) dalam upacara keagamaan tuak dimanfaatkan untuk metabuh (persembahyangan), yang tidak saja disujudkan kehadapan Tuhan Yang Maha Esa/Ida Sang Hyang Widhi Wasa, namun yang utama metabuh juga sebagai pelengkap di dalam upacara mecaru (korban suci kepada bhuta kala). Hal ini dimaksudkan untuk mewujudkan keharmonisan di alam semesta, yaitu antara bhuana alit (tubuh manusia) dengan bhuana agung (alam semesta). Selain dimanfaatkan dalam upacara keagamaan tuak juga dapat dipergunakan sebagai bahan membuat gula (gula Bali) dan sebagai bahan baku minuman keras yaitu minuman arak yang pembuatannya melalui penyulingan tuak tersebut sehingga menghasilkan arak. Tradisi minum minuman keras menjadi suatu fenemona ditengah kehidupan masyarakat Bali, misalnya istilah mearakan yang merujuk pada aktivitas minum arak di sudut-sudut atau warung-warung yang menjual arak di desa (Winata, 2009).

Dalam kehidupan sehari-hari selain digunakan untuk upacara keagamaan, bahan baku gula yang nantinya menjadi sumber penghasilan, tuak biasanya juga dikonsumsi sebagai minuman. Kebiasaan minum-minuman keras merupakan fenomena yang sering kali terjadi di Indonesia. Banyak faktor-faktor yang menyebabkan orang untuk minum-minuman keras, sehingga banyak permasalahan yang timbul dari minum-minuman keras terutama pada remaja saat ini. Dilihat dari sudut pandang hukum, mengkonsumsi miras adalah pola tingkah laku yang bertentangan dengan peraturan perundang-undangan tentang Pengawasan dan Pengendalian Minuman Beralkohol yaitu Undang-Undang Republik Indonesia Nomor 8 Tahun 1976 dan Keppres Nomor 3 Tahun 1997. Menurut beberapa pendapat, alkohol yang terkandung dalam miras memiliki banyak pengaruh negatif bagi kesehatan sehingga miras dilarang diperjual belikan tanpa ijin. Dampak buruk dari kebiasaan minum alkohol mengenai berbagai organ di dalam tubuh, mulai dari otak, mulut, saluran cerna, sampai ke usus besar (Kus Anna, 2012). Selain itu menurut Keputusan Presiden Republik Indonesia Nomor 3 Tahun 1997 Tanggal 31 Januari 1997 tentang Pengawasan dan Pengendalian Minuman Beralkohol menyatakan bahwa minuman beralkohol dapat menimbulkan 
kerugian terhadap kesehatan manusia dan gangguan ketertiban serta ketentraman masyarakat, sehingga perlu dilakukan pengawasan dan pengendalian terhadap produksi, predaran, dan penjualannya.

Dari dampak negatif yang ditimbulkan miras kususnya pada remaja di kota-kota di Indonesia, salah satu kota di Bali yang terkenal dengan penghasil arak dan tuaknya adalah kota Amlapura. Kota yang terletak di timur Pulau Bali ini juga memiliki masalah yang sama yakni masalah miras dalam kehidupan sehari-hari. Salah satu desa penghasil tuak di kota Amlapura adalah Desa Datah. Desa yang berjarak \pm 20 Km dari Kota Amlapura ini memiliki luas wilayah 3.674 Ha dan jumlah penduduk 12.551 jiwa. Dari jumlah penduduk tersebut 6.320 jiwa sebagai petani. Dari data tersebut terlihat banyaknya penduduk yang memiliki mata pencaharian sebagai petani, terutama petani aren. Hal tersebut terbukti dari banyaknya lahan yang ditanami pohon aren di Desa Datah. Selain buah dan daunnya yang dapat dijual, banyak warga memanfaatkan pohon aren tersebut sebagai sumber rejeki dengan menyadap tuak dari pohon tersebut yang nantinya tuak tersebut dijual kepada masyarakat. Dari dampak yang ditimbulkan miras dalam hal ini tuak, sangat berhungan dengan sosial-ekonomi masyarakat. Disamping jelas-jelas miras atau tuak tersebut membawa dampak negatif bagi masyarakat yang mengkonsumsinya juga berdampak positif bagi penjual tuak karena sebagai sumber rejeki dari menjual tuak.

Tidak adanya pekerjaan lain disinyalir merupakan salah satu penyebab masih bertahannya pedagang tuak di Desa Datah, karena kondisi desa yang tandus menyebabkan pekerjaan bercocok tanan lebih cocok dilakukan saat musim hujan saja, karena kondisi desa yang tandus sehingga tanah lebih cocok ditanami pohon aren. Hasil dari buah dan daun pohon aren tersebut juga memerluka waktu untuk memanennya, namun menyadap tuak dapat dilakukan setiap hari sehingga langsung dapat dijual ke konsumen. Jadi menjual tuak dapat dikatakan pekerjaan utama karena dari hasil menjual tuak tersebut mereka langsung dapat gunakan untuk memenuhi kebutuhan hidup keluarga. Keadaan seperti ini yang menyebabkan banyak penjual tuak tidak bisa berbuat banyak untuk hidupnya dan sulit beralih kepekerjaan lain.

\section{Metode}

Penelitian ini merupakan penelitian kualitatif dengan menggunakan pendekatan studi kasus. Studi dilaksanakan di Desa Datah, Kecamatan Abang, Kabupaten Karangasem, Bali. Populasi target pada penelitian ini adalah seluruh petani tuak atau warga yang memiliki pperkebunan aren di Desa Datah. Populasi studi penelitian yaitu pada peminum tuak laki-laki berusia 17 tahun ke atas yang berdomisili dan telah mengonsumsi tuak sekurang-kurangnya selama dua belas bulan. Sampel pada penelitian ini sama dengan populasi studi yang telah disebutkan, yaitu petani pohon aren/petani tuak yang berusia 17 tahun ke atas yang telah mampu menyadap tuak sekurang-kurangnya selama 12 bulan. Pengambilan sampel pada penelitian ini adalah dengan metode simple random sampling melalui kerangka sampel yang tersedia. Sampel yang terpilih secara acak harus memenuhi kriteria untuk dapat menjadi responden, apabila sampel terpilih tidak memenuhi kriteria maka sampel tersebut tidak dapat menjadi responden.

Data yang dikumpulkan oleh peneliti adalah data primer yang diperoleh melalui kuesioner dan wawancara mendalam. Cara Pengumpulan Data Pada pendekatan kuantitatif, responden yang terpilih diminta kesediaannya untuk diwawancara secara terstruktur dengan kuesioner. Pertanyaan dalam kuesioner berupa pertanyaan semi tertutup dengan bahasa yang disesuaikan dan dipahami oleh masyarakat Desa Lumban Siagian Jae. Kemudian pada pendekatan kualitatif, peneltiti melakukan wawancara secara mendalam mengenai tradisi, kepercayaan, kebiasaan keluarga mengonsumsi tuak dan peran petugas kesehatan kepada para informan yang telah disebutkan sebelumnya.

Instrumen penelitian adalah alat-alat yang digunakan untuk pengumpulan data. Instrumen penelitian yang digunakan pada penelitian ini adalah kuesioner yang berisi pertanyaan mengenai pengetahuan, sikap, keluhan kesehatan, tradisi, kepercayaan, peran petugas kesehatan dan kebiasaan keluarga responden mengonsumsi tuak. Sebelum digunakan, kuesioner tersebut dilakukan uji coba terlebih dahulu pada populasi lain yang memiliki karakteristik samadengan responden. Hal ini dilakukan untuk melihat apakah pertanyaan-pertanyaan yang diajukan kepada responden dapat dimengerti atau tidak. Selain itu, instrumen penelitian lainnya adalah panduan wawancara yang digunakan untuk mengetahui tradisi, kepercayaan, peran petugas kesehatan dan kebiasaan keluarga mengonsumsi tuak. Peneliti melakukan probing pada poin-poin pertanyaan saat mewawancarai informan untuk memperoleh informasi mengenai istilah-istilah tersebut secara mendalam.

Kuesioner yang telah dikumpulkan selanjutnya diolah dengan melalui tahapan-tahapan berikut ini sehingga siap untuk dianalisis: a) Mengkode data (data coding), yaitu membuat klasifikasi data dan member kode pada jawaban dari setiap pertanyaan dalam kuesioner. b) Menyunting data (data editing), yaitu kuisioner yang telah diisi dilihat kelengkapan jawabannya, sebelum dilakukan proses pemasukan data ke dalam computer. c) Membuat struktur data (data structure) dan file data (data file), yaitu 
membuat template sesuai dengan format kuesioner yang digunakan. d)Memasukan data (entry data), yaitu dilakukan pemasukan data ke dalam template yang telah dibuat. e) Membersihkan data (data cleaning), yaitu data yang telah di entry dicek kembali untuk memastikan bahwa data tersebut bersih dari kesalahan, baik kesalahan pengkodean maupun kesalahan dalam membaca kode. Dengan demikian diharapkan data tersebut benar-benar siap untuk dianalisis. f) Skoring data, yaitu memberikan skor terhadap jawaban yang menyangkut variabel pengetahuan dan sikap. Penentuan tingkat pengetahuan responden dibagi berdasarkan jumlah benar jawaban responden atas pertanyaan yang diberikan. Nilai 1 diberikan kepada jawaban yang benar dan nilai 0 diberikan kepada jawaban yang salah. Skala pengukuran untuk sikap disesuaikan dengan pernyataan yang diberikan semakin setuju terhadap pernyataan positif maka skor semakin besar, demikian sebaliknya.

\section{Hasil dan Pembahasan}

\section{Minuman Tuak dalam Interaksi Sosial di Desa Datah}

Menurut Soekanto (2005) interaksi sosial merupakan hubungan-hubungan sosial yang dinamis yang menyangkut hubungan antara orang-orang perorangan, antara kelompok-kelompok manusia, maupun antara orang perorangan dengan kelompok manusia. Sedangkan menurut Ruslan (1979) konsep sosial sebagai interaksi antara individu yang bertentangan atau interaksi antara warga masyarakat untuk melakukan suatu hubungan. Menurut Suwantoro (1997) sosial sebagai interaksi antara individu yang bertetangga dan interaksi antara warga masyarakat serta nilai-nilai yang dipergunakan masyarakat itu untuk melakukan hubungan interaksinya. Dari pengertian di atas dapat disimpulkan bahwa sosial adalah interaksi yang berhubungan antara individu yang bertetangga atau interaksi antara warga masyarakat serta nilai-nilai yang dipergunakan masyarakat itu untuk melakukan suatu hubungan yang dinamis.

Dalam kehidupan sehari-hari tuak dimanfaatkan di dalam upacara-upacara keagamaan umat Hindu. Menurut Sri Arnawi (dalam Seputra, 2009) dalam upacara keagamaan tuak dimanfaatkan untuk metabuh (persembahyangan), yang tidak saja disujudkan kehadapan Tuhan Yang Maha Esa/Ida Sang Hyang Widhi Wasa, namun yang utama metabuh juga sebagai pelengkap di dalam upacara mecaru (korban suci kepada bhuta kala). Hal ini dimaksudkan untuk mewujudkan keharmonisan di alam semesta, yaitu antara bhuana alit (tubuh manusia) dengan bhuana agung (alam semesta). Selain sebagai pelengkap upacara keagamaan, tuak juga merupakan minuman beralkohol yang cenderung dikonsumsi saat kegiatan upacara keagamaan, adat istiadat bahkan dijadikan minuman penghilang rasa haus. Hal tersebut terjadi karena didukung oleh kondisi desa yang tandus. Mengkonsumsi tuak (metuakan) dianggap sebagai salah satu kegiatan pemersatu warga dalam kehidupan sosial mereka.

Jika dilihat dari dampak buruk kebiasaan minum alkohol mengenai berbagai organ di dalam tubuh, mulai dari otak, mulut, saluran cerna, sampai ke usus besar (Kus Anna, 2012). Selain itu UndangUndang Republik Indonesia Nomor 8 Tahun 1976 dan Keputusan Presiden Republik Indonesia Nomor 3 Tahun 1997 Tanggal 31 Januari 1997 tentang Pengawasan dan Pengendalian Minuman Beralkohol menyatakan bahwa minuman beralkohol dapat menimbulkan kerugian terhadap kesehatan manusia dan gangguan ketertiban serta ketentraman masyarakat, sehingga perlu dilakukan pengawasan dan pengendalian terhadap produksi, predaran, dan penjualannya. Jadi jika dilihat kenyataan yang ada di Desa Datah menurut Undang-Undang Republik Indonesia Nomor 8 Tahun 1976 dan Keppres Nomor 3 Tahun 1997 sangat bertentangan dilihat dari pengawasan dan pengendalian terhadap produksi, peredaran, dan penjualan tuak tersebut. Pelanggaran terhadap Keppres tersebut dapat dilihat dari masih banyaknya penjual tuak, memang tidak bisa dilepaskan dari tradisi atau adat istiadat yang ada di Kabupaten Karangasem khususnya di Desa Datah. Berikut disajikan minuman tuak dalam tradisi adat istiadat dalam kehidupan masyarakat Desa Datah. 


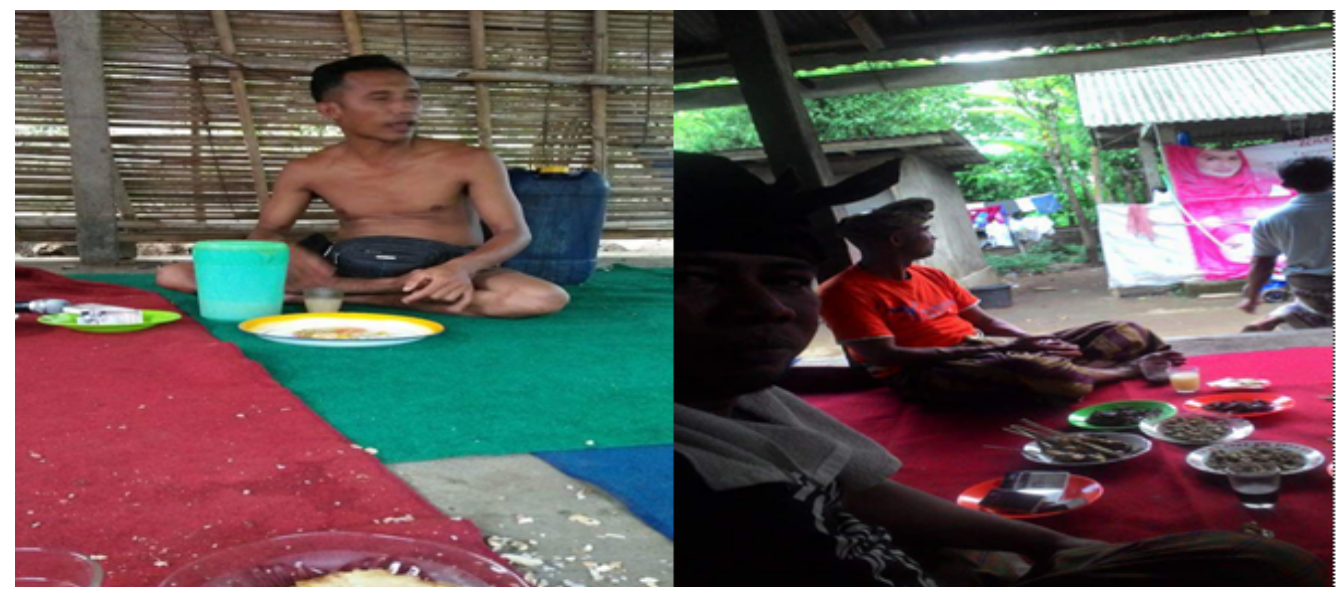

Gambar 1. Tradisi Metuakan dalam Kegiatan Adat di Desa Datah

\section{Minuman Tuak Sebagai Pilihan Ekonomis Pohon Aren dalam Menunjang Perekonomian di Desa} Datah

Menurut Soekanto (dalam Sumarto, 2006) ekonomi sebagai setiap sistem hubungan-hubungan yang menentukan alokasi sumber daya yang terbatas atau yang langka. Sedangkan menurut Ruslan (1979) konsep ekonomi mengandung pengertian berbagai usaha yang dilakukan oleh manusia dalam usaha memenuhi kebutuhan hidupnya. Sedangkan Suwantoro (1997) ekonomi mengandung pengertian berbagai usaha yang dilakukan oleh manusia dalam memenuhi kebutuhan hidupnya. Jadi dari pengertian di atas dapat disimpulkan bahwa ekonomi adalah setiap sistem hubungan-hubungan yang menentukan alokasi sumber daya yang terbatas atau yang langka dalam berbagai usaha yang dilakukan oleh manusia untuk memenuhi kebutuhan hidupnya.

Menjual minuman tuak di Desa Datah merupakan pekerjaan utama, hal ini dikarenakan menyadap tuak dapat dilakukan setiap hari yang dimana setiap pohon aren mampu menghasilkan empat sampai 20 liter perhari tergantung jumlah pohon kelapa dan pohon aren yang dimiliki. Hasil menyadap tuak tersebut dijual kepengepul tuak yang ada di Desa Datah dan bahkan ada pembeli yang langsung datang ke rumah penjual tuak sehingga dari uang menjual tuak tersebut dapat digunakan untuk kebutuhan hidup keluarganya. Masyarakat tidak dapat menjadikan pekerjaan berkebun sebagai mata pencaharian utama seperti di daerah lain karena berkebun hanya dapat dilakukan saat musim hujan saja, hal tersebut dikarenakan kondisi desa yang tandus. Tetapi walaupun demikian dari berkebun tersebut juga dapat cukup membantu untuk dapat digunakan sebagai konsumsi sendiri, karena mereka hanya dapat menanam ubi, singkong, dan sesekali menanam sayur-sayuran seperti kacang-kacangan.

Pohon aren yang tumbuh di kebun penjual tuak juga memerlukan waktu untuk memanen buah dan daun pohon tersebut. Apabila pemanfaatan pohon aren tersebut dari hasil menyadap tuak maka buah yang dihasilkan tentunya sangat berkurang atau bahkan tidak menghasilkan buah. Hal tersebut dikarenakan menyadap tuak melalui proses pemotongan pucuk buah kelapa atau buah aren yang masih muda sehingga keluar getah yang berupa tuak. Selain hasil berupa minuman keras (tuak), pohonya juga dapat memberikan manfaat ekonomis bagi pemilik pohon aren tersebut. Daun pohon aren dikatakan dapat memberikan manfaat ekonomis dikarenakan hasil dari daun pohon aren tersebut dapat dijual yang untuk selanjutnya dapat dimanfaatkan sebagai sarana upacara keagamaan. Berikut disajikan hasil produk dari daun pohon aren.

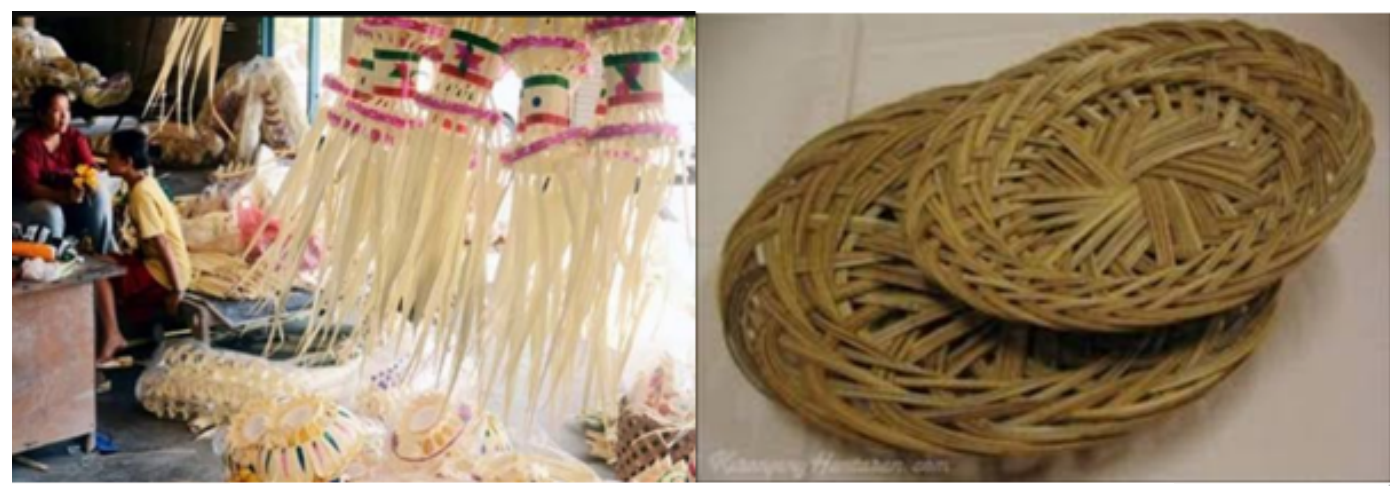

Gambar 2. Produk Dari Duan dan Batang Daun Pohon Aren 
Hasil dari buah dan daun pohon aren tersebut juga memerlukan waktu untuk memanennya, namun menyadap tuak dapat dilakukan setiap hari sehingga langsung dapat dijual ke konsumen. Jadi menjual tuak dapat dikatakan sebagai pilihan pekerjaan utama karena dari hasil menjual tuak tersebut mereka langsung dapat gunakan untuk memenuhi kebutuhan hidup keluarga. Mudahnya proses dan cepatnya hasil yang diperoleh masyarakat itulah yang mendasari menjual tuak menjadi pilihan utama masyarakat untuk hidupnya dan sulit beralih kepekerjaan lain.

\section{Pohon Aren dan Minuman Tuak Potensi Pembangunan Ekonomi Daerah}

Masalah pokok dalam pembangunan daerah adalah terletak pada penekanan terhadap kebijakankebijakan pembangunan yang didasarkan pada kekhasan daerah yang bersangkutan dengan menggunakan potensi sumberdaya manusia, kelembagaan dan sumber fisik secara lokal (daerah). Pembangunan ekonomi daerah adalah suatu proses dimana pemerintah daerah dan masyarakatnya mengelola sumber daya-sumber daya yang ada dan membentuk suatu pola kemitraan antara pemerintah daerah dengan sektor swasta untuk menciptakan suatu lapangan kerja baru dan merangsang perkembangan kegiatan ekonomi (pertumbuhan ekonomi) dalam wilayah tersebut.

Bertolak dari itu, daerah diberikan kebebasan untuk menggali dan mengembangkan faktor produksi salah satunya sumber daya alam yang ada pada daerahnya untuk mensejahterakan masyarakatnya. Salah satu sumber daya alam tersebut adalah pohon aren. Desa Datah, karena kondisi desa yang tandus menyebabkan pekerjaan bercocok tanam lebih cocok dilakukan saat musim hujan saja. Dengan kondisi wilayah yang tandus sehingga tanah lebih cocok ditanami pohon kelapa dan pohon aren. Pohon aren dapat lebih dimanfaatkan sebagai sumber pendapatan masyarakat yang membawa pertumbuhan perekonomian daerah yang lebih baik. Sudah barang tentu untuk dapat meningkatkan pendapatan masyarakat dan pertumbuhan ekonomi daerah diperlukan adanya pemberdayaan daripada masyarakatnya itu sendiri.

Dalam kaitannya dengan pembangunan perekonomian daerah, pendekatan pembangunan yang digunakan diarahkan kepada penerapan program pemberdayaan ekonomi rakyat dimaksudkan untuk dapat mengakomodasikan aspirasi dan tuntutan masyarakat yang dilandasi oleh hasrat untuk lebih berperanserta dalam pembangunan. Dalam rangka itu, perlu dibangun iklim kemasyarakatan yang dapat menumbuhkembangkan prakarsa dan rasa tanggung jawab serta kesediaan masyarakat untuk berperan secara lebih sadar dan aktif dalam menjawab tantangan pembangunan, yang perlu pula dibarengi dengan penciptaan semangat kebersamaan diantara semua pelaku pembangunan secara lintassektoral, antara pemerintah dan nonpemerintah, dan antar kelompok masyarakat. Kondisi inilah yang sangat penting dikembangkan di Desa Datah sebagai penghasil pohon aren. Selama ini masyarakat hanya berjalan sendiri-sendiri dalam rangka untuk pemenuhan ekonomi sehingga apa yang dihasilkan belum maksimal, padahal pohon aren juga memiliki potensi lain selain buahnya dapat digunakan sebagai minuman dan sarana upacara. Belum maksimalnya pemanfaatan pohon aren dalam upaya meningkatkan perekonomian dikarenakan salah satunya adalah kemampuan masyarakat untuk mengolah hasil dari pohon aren terbatas.

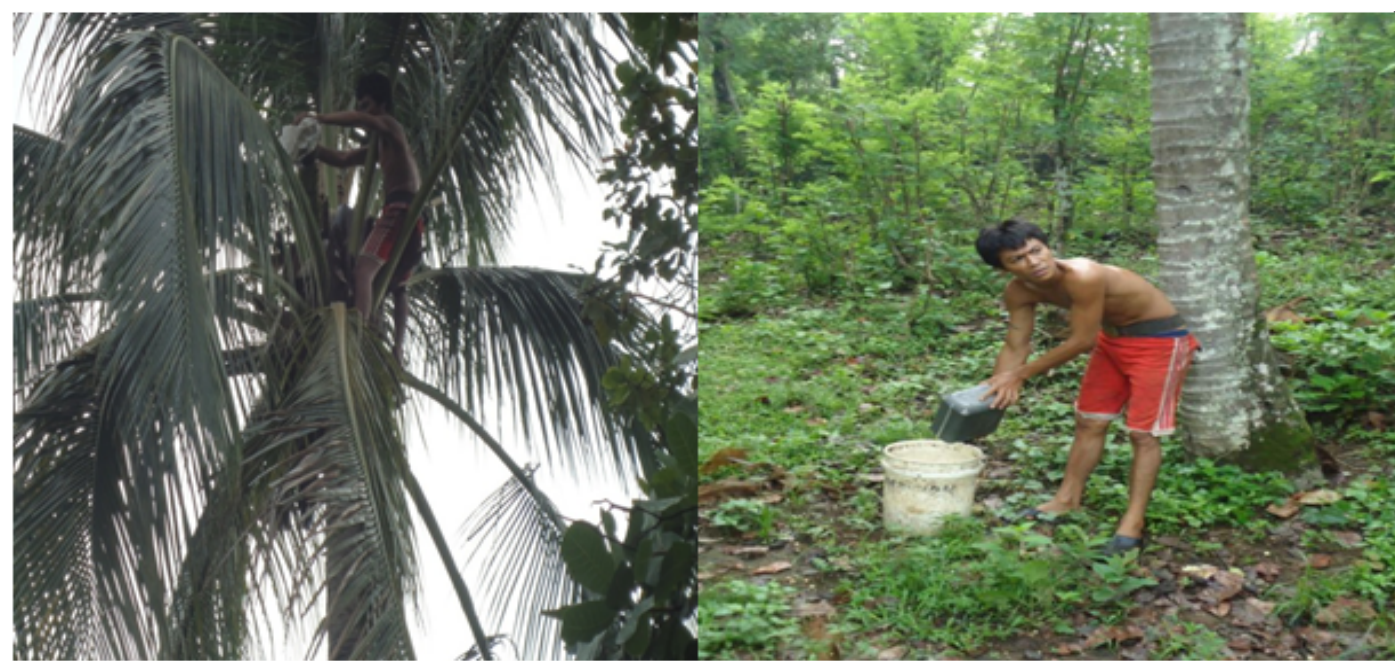

Gambar 3. Proses Penyadapan Tuak dari Pohon Aren dan Siap untuk Dijual 
Pembuatan tuak sangat mudah, alami dan sangat konvensional sehingga masyarakat yang dengan keterbatasan keterampilan cenderung untuk melakukan itu. Padahal salah satu potensi lain dari minuman tuak adalah dapat digunakan sebagai bahan baku pembuatan gula. Seperti yang kita ketahui bahwa hampis semua makanan yang kita konsumsi menggunakan gula sebagai bahan pokok. Untuk itu perlu diupayakan adanya sinergitas antara pemerintah, swasta dan masyarakat. Pemerintah dan swasta dapat menjadi mitra usaha dalam rangka untuk pemenuhan ekonomi masyarakat dan peningkatan pembangunan ekonomi daerah. Peran pemerintah dan swasta tersebut dapat diwujudkan dengan adanya bantuan modal usaha dan pelatihan pengolahan hasil pohon aren selain tuak, dengan demikian masyarakat dapat lebih kreatif menciptakan produk dari sumber daya alam yang dimiliki sebagai upaya pemenuhan ekonomi masyarakat dan peningkatan ekonomi daerah.

\section{Simpulan dan Saran}

Jika dilihat kenyataan yang ada di Desa Datah menurut Undang-Undang Republik Indonesia Nomor 8 Tahun 1976 dan Keppres Nomor 3 Tahun 1997 sangat bertentangan dilihat dari pengawasan dan pengendalian terhadap produksi, predaran, dan penjualan tuak tersebut. Pelanggaran terhadap Keppres tersebut dapat dilihat dari masih banyaknya penjual tuak memang tidak bisa dilepaskan dari kehidupan sosial masyarakat yang ditunjukkan dengan tradisi atau adat istiadat yang ada di Kabupaten Karangasem khususnya di Desa Datah. Selain itu, dalam kehidupan sehari-hari tuak selain sebagai minuman beralkohol juga dimanfaatkan di dalam upacara-upacara keagamaan umat Hindu. Melihat dari begitu banyak kebermanfaatan tuak mendorong masyarakat untuk tetap eksis menggeluti profesi tersebut dalam upaya pemenuhan kebutuhan ekonomi walaupun agak bertentangan dengan hukum. Selain hal tersebut eksisnya profesi menjual tuak juga dikarenakan tidak adanya pekerjaan lain di Desa Datah, karena kondisi desa yang tandus menyebabkan pekerjaan bercocok tanan lebih cocok dilakukan saat musim hujan saja, karena kondisi desa yang tandus sehingga tanah lebih cocok ditanami pohon aren sebagai penghasil tuak.

Melihat banyak potensi yang dapat dikembangkan dari adanya pohon aren selain penghasil minuman tuak, maka dari itu perlu adanya sinergitas antara pemerintah, swasta dan masyarakat. Pemerintah dan swasta dapat menjadi mitra usaha dalam rangka untuk pemenuhan ekonomi masyarakat dan peningkatan pembangunan ekonomi daerah.

\section{Daftar Pustaka}

Ardiantara, Gede. (2011). Analisis Sosial-Ekonomi Pemulung di Tempat Pembuangan Akhir (TPA) Bengkala Tahun 2011. Skripsi. Jurusan Pendidikan Ekonomi, Fakultas Ilmu Sosial, Universitas Pendidikan Ganesha.

Damsar. (2002). Sosiologi Ekonomi. Jakarta: PT .Raja Grafindo Persada.

Dinas Tenaga Kerja dan Transmigrasi Kabupaten Karangasem. (2012). Upah Minimum Kabupaten/Kota.

Dinas Sosial Kabupaten Karangasem. (2012). Kriteria KK Penerima Bantuan Bedah Rumah.

Ismail, Muhammad Ilyas. (2010). "Pendidikan Wajib Belajar (Wajar) 9 Tahun dan Peningkatan Kwalitas Sumber Daya Manusia". Tersedia pada http://www.gudangmateri.com/2010/06/pendidikanwajib-belajar-9 tahun. html (diakses tanggal 10 Juni 2012).

Kantor Pelayanan, Penyuluhan, dan Konsultasi Perpajakan Kabupaten Karangasem. (2012). Daftar Jenis Barang Kena Pajak yang Tergolong Mewah Selain Kendaraan Bermotor yang Dikenakan Pajak Penjualan Atas Barang Mewah dengan Tarif Sebesar 10\% (sepuluh persen).

Kus Anna, Lusia. (2012). “Efek Minuman Keras Bukan Cuma Mabuk”. Tersedia pada http://health.kompas.com/read/2012/01/16/11462744/ Efek.

Minuman.Keras.Bukan.Cuma.Mabuk (diakses tanggal 10 Juni 2012).

Nasution, Zulkarnain, dkk. (2006). Kompilasi Peraturan Perundang-Undangan tentang Narkoba. Jakarta: Penerbit Prenada Media Group.

Ruslan. (1979). Ekonomi Sumber Daya. Bandung: Alumni. 
Seputra, I Kadek. (2009). Metuakan sebagai Ritual Sosial di Desa Nawa Kerti, Kec. Abang, Kab. Karangasem, Bali. Skripsi. Jurusan Pendidikan Sejarah, Fakultas Ilmu Sosial, Universitas Pendidikan Ganesha.

Singarimbun, Masri. (1996). Penduduk dan Perubahan. Yogyakarta: Pustaka Pelajar.

Soekanto, Soerjono. (2005). Sosiologi Suatu Pengantar. Jakarta: PT. Raja Girafindo Persada.

Sudiarta, I Gede. (2011). Eksistensi Tradisi Metuakan di Tengah-tengah Dinamika Modernisasi di Desa Pakraman Sekar Gunung Kecamatan Karangasem Kabupaten Karangasem-Bali. Skripsi. Jurusan Pendidikan Geografi, Fakultas Ilmu Sosial, Universitas Pendidikan Ganesha.

Winardi. (1998). Pengantar Ilmu Ekonomi. Bandung: PT. Tarsito.

Ilyas, S. (2013). Evaluasi Kualitas Spermatozoa Dan Jumlah Turunan Mencit (Mus musculus L.) (F1) Setelah Pemberian Tuak.Prosiding Semirata FMIPA Universitas Lampung.

Ikegami, S. (1997). Tuak dalam Masyarakat Batak Toba: Laporan Singkat tentang Aspek Sosial-budaya Penggunaan Nira. Annual Report of the University of Shizuoka, Hamamatsu College. 